\title{
PENANGANAN LIMBAH FENOL DENGAN PEROKSIDASE HASIL ISOLASI DARI LOBAK (HORSERADISH)
}

\author{
Damin Sumardjo ${ }^{1)}$ dan Wuryanti ${ }^{2)}$ \\ 1) Laboratorium Kimia, Fakultas Kedokteran Universitas Diponegoro - Semarang \\ 2) Laboratorium Biokimia, Jurusan Kimia FMIPA Universitas Doponegoro-Semarang
}

\begin{abstract}
ABSTRAK
Dalam air limbah industri, banyak dijumpai komponen fenol yang besifat racun. Karena itu pada penelitian ini dicoba untuk menghilangkan komponen fenol dengan cara proses enzimatik. Enzim yang digunakan adalah peroksidase yang berasal dari jenis tumbuhan yaitu lobak (Horseradish). Lobak seberat $0,5 \mathrm{~kg}$ dihomogenkan dalam blender dengan $100 \mathrm{~mL} \mathrm{~K}_{2} \mathrm{HPO}, 0.1$ $\mathrm{M}$, disaring, ditambahkan $\left(\mathrm{NH}_{4}\right)_{2} \mathrm{SO}_{4}$ secara bertingkat $(0-5 \%, 5-20 \%, 20-40 \%, 40-65 \%)$ dalam supematan, kemudian dipisahkan. Endapan yang didapat ditambah buffer Tris-HCl 0,05 M pII 7 dan didialisis dengan menggunakan membran selopan selama 12 jam dengan buffer yang sama. Hasil ekstrak kasar dan fraksinasi dengan kejenuhan yang berbeda terhadap $\left(\mathrm{NII}_{4}\right)_{2} \mathrm{SO}_{4}$ diaplikasikan pada sampel limbah. Setelah dilakukan uji pendahuluan, $0,5 \mathrm{~mL}$ air limbah ditambah $0,3 \mathrm{~mL} \mathrm{H}_{2} \mathrm{O}_{2} \quad 0,1 \mathrm{M}$ dan $3 \mathrm{~mL}$ enzim ekstrak kasar dan hasil dialisis. Setelah dianalisa, kadar fenol dalam limbah dapat diturunkan dari $1,068 \mathrm{ppm}$ menjadi $0,689(35,53 \%)$, $0,436(59,13 \%), 0,641(39,96 \%), 0,736(31,09 \%)$, dan $0,783 \mathrm{ppm}(26,66 \%)$ masing-masing untuk ekstrak kasar, dan hasil dialisis $0-5 \%, 5-20 \%, 20-40 \%, 40-65 \%$. Dari hasil eksperimen di atas dapat disimpulkan bahwa semakin besar kandungan enzim semakin besar pula penurunan kadar fenol dalam air limbah.
\end{abstract}

\section{PENDAHULUAN}

Dalam air limbah industri, banyak dijumpai komponen fenol yang bersifat racun. Karena itu pada penelitian ini, dicoba untuk menghilangkan komponen fenol dengan cara proses enzimatik.
Enzim yang digunakan adalah peroksidase.

Peroksidase banyak terdapat pada tumbuhan, hewan, dan mikroba. Pada tumbuhan salah satunya adalah berasal dari lobak (Horseradish). Peroksidasc merupakan katalis yang spesifik untuk 
mengoksidasi

fenol

menambahkan hidrogen peroksida.

Penelitian ini bertujuan untuk menentukan berapa besar peneurunan kadar fenol dalam air limbah setelah perlakuan dengan peroksidase.

Dalam industri MIGAS senyawa fenol ini terbawa kepermukaan yang kemudian akan berada dalam air limbah setelah mengalami proses pemisahan dari minyak bumi. Keberadaan fenol dalam air limbah sering bersumber dari pemakaian bahan kimia tertentu, terutama pada proses pemurnian minyak mentah (refining petroleum). Minyak mentah terdiri dari berbagai macam zat anorganik yang sangat kotor sehingga akan merugikan operasi pada unit pengolahan. Oleh sebab itu perlu dihilangkan atau kadarnya diturunkan sebelum masuk ke proses destilasi dengan proses desalting ${ }^{(1)}$.

Peroksidase menggunakan hidrogen peroksida sebagai oksidator. Peroksidase membentuk kompleks dengan hidrogen peroksida yang kemudian pecah menjadi dua radikal hidroksi. Kemudian terjadi pengambilan dua hidrogen dari substrat oleh .. radikal hidroksi. Karena pengambilan dua atom hidrogen tersebut secara berturutan, maka akan terjadi radikal intermediet yang kemudian dapat meluruh secara spontan. Peroksidase dapat juga menginduksi perangkaian oksidatif dari fenol dengan adanya hidrogen peroksida ${ }^{(2)}$. Secara umum reaksinya adalah,

$\mathrm{HOOH}+2 \mathrm{SH} \stackrel{\text { Peroksidase }}{\longrightarrow} 2 \mathrm{H}_{2} \mathrm{O}+2 \mathrm{~S}$

Dalam reaksi rantai, $\mathrm{H}_{2} \mathrm{O}_{2}$ akan bereaksi cepat dengan fenol dan 4aminoantipirin (donor elektron) dengan adanya peroksidase, dan akan menghasilkan quinoneimine dimana intensitas warna maksimum dengan absorbansi pada $\quad 510 \mathrm{~nm}$. Reaksinya adalah,

\section{$\mathrm{H}_{2} \mathrm{O}_{2}+$ fenol +4 -aminoantipirin}

$$
\stackrel{\text { peroksidase }}{\longrightarrow} \text { quinoneimine }+\mathrm{H}_{2} \mathrm{O}
$$

Jumiah peroksidase akan dìpengaruhi oìch jumlah quinoneimine yang terbentuk. Terdapat hubungan linier antara kuantitas peroksidase dalam larutan dengan intensutas warna yang terbentuk, dimana intersitas warna dapat diukur dengan spektrofotometer. ${ }^{(3)}$

\section{EKSPERIMEN}

(a) Limbah fenol yang digunakan sebagai sampel diperoleh dari Pertamina Cilacap. Diambil $100 \mathrm{~mL}$ sampel kemudian 
ditambah $\mathrm{NaOH}$ 0,1 M sampai pH 12,5. Setclah itu diekstraksi 2 kali dengan 15 $\mathrm{mL} \mathrm{CCl}_{4}$. Fasa air yang diperoleh ditambah $\mathrm{HCl}$ 0,1 M sampai $\mathrm{pH} 4,5$, kemudian diekstraksi lagi 3 kali dengan $10 \mathrm{~mL} \mathrm{CHCl}_{3}$. Fasa organik yang diperoleh ditambah $1,5 \mathrm{~mL} \mathrm{NH}_{4} \mathrm{Cl} 10 \%$, ditambah $\mathrm{NH}_{4} \mathrm{OH} 40 \%$ sampai $\mathrm{pH} 10$, ditambah $0,3 \mathrm{~mL} \mathrm{~K} 3 \mathrm{Fe}(\mathrm{CN}) 68 \%$, dan ditambah $0,3 \mathrm{~mL} 4$-AAP $2 \%$ kemudian digojog selama 10 menit. Kemudian diukur absorbansinya pada panjang gelombang $505 \mathrm{~nm}$ dengan spektrofotometer UV/VIS. (b) Lobak segar seberat $0,5 \mathrm{~kg}$ dihomogenkan. dengan $100 \mathrm{~mL}$ K2HPO4 $0,1 \quad \dot{M}$ kemuđian diblender, dan disaring. Supernatan yang diperoleh ditambah (NH4)2SO4 secara bertingkat $(0-5 \%, 5-$ $20 \%, \quad 20-40 \%, \quad 40-65 \%$ ), kemudian dipisahkan dengan sentrifuge $3400 \mathrm{rpm}$. Enđapan yang didapat ditambah buffer Tris- $\mathrm{HCl} 0,05 \mathrm{M} \mathrm{pH} 7$ dan didialisis dengan buffer yang sama. Ekstrak kasar dan hasil dialisis untuk kejenuhan yang berbeda diaplikasikan pada limbah. Uji aktivitas menggunakan rumus $u / m L=$ (A.B)/(a.b.t.v). (4) $\quad$ (c) Uji protein digunakan metode Lowry. Sebanyak 0,6 $\mathrm{mL}$ sampel yang mengandung protein. ditambah $3 \mathrm{~mL}$ Lowry $\mathrm{C}$, kemudian didiamkan selama 20 menit pada temperatur kamar. Setelah itu ditambah $0,3 \mathrm{~mL}$ folin, didiamkan selama 45 menit pada temperatur kamar. Absorbansi dibaca pada panjang gelombang $650 \mathrm{~nm} .{ }^{(5)}$ (d) Perlakuan sampel oleh enzim : 0,4 mL air limbah ditambah $0,3 \mathrm{~mL} \mathrm{H}_{2} \mathrm{O}_{2}$ dan $3 \mathrm{~mL}$ larutan enzim, dikocok selama 10 menit, kemudian absorbansi diukur pada panjang gelombang $505 \mathrm{~nm}$.

\section{HASIL DAN PEMBAHASAN}

Enzim dari Ekstrak kasar (Ek) dan hasil dialisis $0-5 \%$ (F1), $5-20 \%$ (F2), 20-40\% (F3), $\quad 40-65 \% \quad$ (F4) masing-masing mempunyai aktivitas (dalam u/mL) adalah 1,$725 ; 4,819 ; 1,865 ; 1,229$; dan 1,106. Masing-masing enzim kasar dan hasil dialisis dapat menurunkan kadar fenol dalam air limbah dari $1,068 \mathrm{ppm}$ menjadi $0,689(35,53 \%), 0,436(59,13 \%)$, $0,641 \quad(39,69 \%), 0,736 \quad(31,09 \%)$, dan $0,783 \mathrm{ppm}(26,66 \%)$. Dari hasil ini tampak bahwa peningkatan aktivitas enzim sebanding dengan bertambahnya penurunan kadar fenol. Dengan demikian, penurunan kadar fenol dalam air limbah akan semakin besar dengan semakin besarnya aktivitas enzim Hasil ini juga berarti bahwa peroksidase dapat menurunkan kadar fenol dengan cukup baik. 


\section{KESIMPULAN DAN SARAN}

Dari hasil dan pembahasan yang telah dikemukanan di atas dapat diambil kesimpulan sebagai berikut :

1. Peroksidase dapat menurunkan kadar fenol dalam air limbah.

2. Besarnya penurunan kadar fenol sebanding dengan aktivitas enzim.

Dan dari hasil peneitian ini dapat disarankan :

1. Melakukan penelitian lebih lanjut dengan kemurnian enzim yang lebih tinggi.

2. Melakukan penelitian dengan sumber enzim yang berbeda.

Ucapan Terimakasih. Ucapan terimakasih kepada saudara Yohan Hidayat yang telah dengan tekun membantu memperoleh data penelitian ini.

\section{REFERENSI :}

1) E. Suhardono, K. Mudjirahardjo, $\mathrm{S}$. Soekapradjo (1995), "Analisis Senyawa Fenolik Dalam Air Limbah MIGAS Dengan Kromatografi Gas", Lembaran Publikasi PPT MIGAS No. 10/11//08/1995, halaman 16-28.

2) Aida

Soeleman, (1995), "Penghilangan atau Penurunan Kadar Fenol Dalam Air Limbah Dengan Menggunakan Enzim Peroksidase", Buletin Penelitian, Vol. Xvii, No.4, Deprind, halaman 1-7.

3) Paolo Monitto, (1980), "Biosintesis Produk Alami", Elis Harwood Publishers John Willey and Sons, New York, halaman 90-101.

4) P. Tijssen, (1985), "Practice and Theory of Enzyme Immunoassay", Vol. 15, Elsevier Science Publisher, Tokyo, pp. 175-180.

5) Robert, K. Scopes, (1987), "Protein Purification Principles and Practice". 2nd ed., Springer-Verlag, Berlin, pp. 302-306. 